\title{
CAUSATION IN MEDICAL MALPRACTICE
}

\author{
Nina Mišić Radanović, PhD, Assistant Professor \\ University of Split, University Department of Forensic \\ Ruđera Boškovića 33, 21000 Split, Croatia \\ nina.misic.radanovic@unist.hr
}

\author{
Ivan Vukušić, PhD, Assistant Professor \\ University of Split, Faculty of Law \\ Ul. Domovinskog rata 8, 21000 Split, Croatia \\ ivan.vukusic@pravst.hr
}

\begin{abstract}
Court proceedings in the field of medical law are currently a growing issue given the increasing migration of doctors and medical staff. Because of that fact, it is crucial to establish the standard of quality of health protection in the European Union (EU). Following the presentation of the existing levels of protection connected with the prevention of malpractice, the paper distinguishes between the legal documents of the EU and the Council of Europe because many documents related to health care and quality are adopted in the EU and in the Council of Europe. The general conclusion is that there is no uniform or cross-sectoral definition of quality in health care, however it has been found that important elements of health care quality include effectiveness, efficiency, access, safety, equity, appropriateness, timeliness, acceptability, satisfaction, patient responsiveness or patient-centeredness, and continuity of care. The health care aspect is analysed in the continental legal system and the common law legal system. The issue of causation is observed through different theories in the continental legal system and various case law examples in the common law legal system. The authors concluded that it would be preferable to adopt a theory of objective imputation as a legal standard for causation in criminal liability in medicine, because it analyses several possible causes in close or remote connection with the resulting consequence, i.e. said theory considers as relevant only the legal causes that result in a harmful event through the violation of due diligence. The paper primarily deals with criminal liability for malpractice, but it also presents the civil aspects in the states (for example the USA) which recognise only civil liability for malpractice.
\end{abstract}

Keywords: causation, criminal law, malpractice, quality 


\section{INTRODUCTION}

In the last few decades, medicine has become the subject of many judicial proceedings, and people have become acquainted with the technological advances through media outlets and publicity. ${ }^{1}$ Hyper-specialisation in every field of medicine requires specific expertise in the analysis and evaluation of the clinical case in question if damage is committed. ${ }^{2}$ Today we are also witnessing a considerable wave of migration among the physicians in the EU. Therefore, it is important to assess its potential impact on the quality of care. Directive 2005/36/EC of the European Parliament and of the Council of 7 September 2005 on the recognition of professional qualifications assumes that all EU doctors meet the same professional standards. However, a number of high-profile incidents of medical malpractice among the migrating EU doctors have raised concerns about the potential risks for safety and the quality of care. The mobility of patients between EU Member States has also drawn attention to the quality of care and the regulations of each Member State related to the quality and causation in the event of medical malpractice. ${ }^{3}$ In order to reduce malpractice, the health care organisation uses the following training procedures to assess the competency and training needs of its workforce: the implementation of a mandatory training programme to meet the requirements arising from these standards, the provision of access to training to meet the safety and quality training needs, and the monitoring of the participation of the workforce in the training.

In order to analyse causation, the paper initially focusses on the standards prescribed in EU legal documents and the documents of the Council of Europe.

Malpractice causation requires the establishment of a correlation between an act and the standard of care that has not been complied with. For that purpose, the paper analyses the standards of care prescribed in the Declaration on the Promotion of Patient Rights in Europe, the Convention on Human Rights and Biomedicine, the Treaty of Maastricht, the Lisbon Treaty amending the Treaty on European Union (TEU) and the Treaty Establishing the European Community (TEC), the European Charter of Patients' Rights - Basic Document, ECJ ruling and Directive 2011/24/EU of the European Parliament and of the Council.

Vojković, H., Gradanskopravni standard medicinskog tretmana, Zbornik radova Pravnog fakulteta u Splitu, Vol. 56, no. 3, 2019, p. 568

2 Ferrara, S. D. et al., Malpractice and medical liability. European Guidelines on Methods of Ascertainment and Criteria of Evaluation, Int J Legal Med, vol. 127, no. 3, 2013, p. 546

3 Footman, K. et al., Cross-border health care in Europe, Denmark, 2014, p. 29; More information about causality and malpractice, and the elements of criminal offence of malpractice in Croatia can be found in Roksandić Vidlička, S., Kaznena djela protiv zdravlja ljudi in Cvitanović, L. et al., Kazneno pravoPosebni dio, Zagreb, 2018 
The following section analyses causation. The establishment of causation is a rather complex element of the evidentiary procedure, because a medical intervention conducted lege artis does not always guarantee the expected outcome. The term outcome is used because causation issues generally occur in result crimes. Causation is connected with a medical error and a subsequent consequence as two different terms that have different legal effect.

Further analysis deals with two different legal systems: continental and common law. These systems are described in separate chapters. In the continental legal system, a competence of various courts in the EU is shown through the theory of equivalence, the theory of adequacy and, most importantly, the concept of objective imputation in criminal matters. All these theories illustrate different ways of establishing whether the standard of quality of medical care is achieved in each case. A special emphasis is on the relationship between the judge and the expert medical witness, including the potential issues that may arise in that particular case.

The common law legal system is analysed through criminal law and the cases pertaining to the United Kingdom. The analysis of the common law system also includes the USA, even though the provisions regulating medical matters in the USA do not recognise criminal liability, but all cases are conducted on the basis of civil liability.

The aim of the paper is to provide an overview of different solutions for establishing the criteria for causation and different standards prescribed in various documents across Europe. Upon analysing different theories of causation, the focus will be placed on the most appropriate theory of objective imputation.

\section{STANDARDS OF PROTECTION IN EUROPE}

Since EU documents refer to quality, the issue of interpretation of the term and its application to individual cases is essential for the establishment of causation. The Court of Justice has not only referred to "medical science and medical standards", 4 "existing scientific literature and studies, the authorised opinions of specialists [etc.]", 5 but it has also emphasised the significance of "taking into consideration

4 Case C-157/99 B.S.M. Geraets-Smits v Stichting Ziekenfonds VGZ and H.T.M. Peerbooms v Stichting CZ Groep Zorgverzekeringen [2001] ECR I -404, \$92

$5 \quad I b i d$. $\$ 98 ; E C J$ decided that normal treatment provided by insurance company or financed by national law, must be understood as treatment / examination according to international medical science and medical standards accepted at the international level. Roksandić Vidlička, op. cit., note 3, p. 265 
all the relevant medical factors and the available scientific data". ${ }^{6}$ Therefore, it seems that there is a place for both the scientific approach on the one hand, and empirical experience on the other hand. The European states, to a large extent, meet these standards of quality through the obligation to provide treatment in compliance with the current international state of science because the treatment of patients must be adequate and appropriate. ${ }^{7}$

An important document for the quality standard was adopted at the European Patient Rights Conference in Amsterdam in 1994, where the World Health Organization (WHO) adopted the Declaration on the Promotion of Patient Rights in Europe ${ }^{8}$, which encompasses the most important patient rights. The Amsterdam Declaration is the first comprehensive international document proclaiming patients' rights and urging states to adopt laws and rules defining the rights and responsibilities of patients, medical professionals and health care institutions. Art. 2. $\$ 1-9$ regulates the patient's right to information about available health services; personal health status; intended medical interventions and their potential risks and benefits, the alternatives to the proposed treatment, diagnosis, prognosis and course of medical treatment, the patient's right not to be informed about his or her medical condition. All listed rights and risks may result in medical error and as such are relevant for determining causation. Moreover, human rights apply not only to patients, but to health workers as well, after they have been adopted in national legal systems. ${ }^{9}$

The most important European document in the field of medical law adopted by the Council of Europe is the Convention for the Protection of Human Rights and Dignity of the Human Being with regard to the Application of Biology and Medicine: the Convention on Human Rights and Biomedicine (known as the Oviedo Bioethical Convention), which entered into force on 1st December 1999. The fundamental principle prescribed by the Oviedo Bioethical Convention is that all people should enjoy the benefits of the same high ethical standards in medicine and science.

6 Case C-173/09 Georgi Ivanov Elchinov v Natsionalna zdravnoosiguritelna kasa, [2010] ECR I - 581, $\$ 62$

7 Patients' Rights in the European Union Mapping eXercise, Final Report, available at: [https://ec.europa.eu/health/sites/health/files/cross_border_care/docs/2018_mapping_patientsrights_frep_en.pdf], pp. 43-44, accessed on 10. June 2020

8 A Declaration on the Promotion of Patient's Rights in Europe, ICP/HLE 121, World Health Organization, 28 June 1994. Available at [ http:// www.who.int/genomics/public/eu_declaration1994.pdf services_co108_en.pdf], accessed on 10. June 2020

9 Cohen, J.; Ezer, T., Human rights in patient care: A theoretical and practical framework, Health and Human Rights, vol. 15, no. 2, 2013, p. 10 
The European Union is a supranational organisation established by a series of treaties. The degree of standard of public health care was initially introduced in the Treaty of Maastricht in 1993. Article 129 (amended and renumbered as Article 152 of TEC and today as Art. 168. of TFEU) provided that "the Community shall contribute towards a high level of human health protection by encouraging co-operation between Member States, and, if necessary, lending support to their action". The Community had no jurisdiction to harmonise national laws, hence it was limited to a cooperation of policies or programmes. ${ }^{10}$ Evidently, all standards must be prescribed within the national legislation and as such applied when determining causation in each case. In terms of harmonisation of national law via EU law (i.e. positive integration), the Member States are still responsible "for the definition of their health policy and for the organisation and delivery of health services and medical care", which includes "the management of health services and medical care and the allocation of the resources assigned to them" ${ }^{11}$ Hence, it derives that a uniform and cross-sectoral definition of quality standard in health care cannot be established. ${ }^{12}$ However, a common conclusion is that the most important elements of health care quality include effectiveness, efficiency, access, safety, equity, appropriateness, timeliness, acceptability, satisfaction, patient responsiveness or patient-centeredness, and continuity of care. ${ }^{13}$

The EU's legislative activity is also reflected in the adoption of declarations, recommendations and directives in the field of medicine and health ${ }^{14}$, such as the European Charter of Patients' Rights - Basic Document ${ }^{15}$, and in the organisation of the Active Citizenship Network in Rome 2002. Art. 8 of the European Charter of Patients' Rights prescribes the right to the observance of quality standards, so that each individual is granted access to high quality health services on the basis of the specification and observance of precise standards. Art. 9 regulates that each individual has the right to be free from harm caused by the poor functioning of health services, medical malpractice and errors, and the right of access to health services and treatments that meet high safety standards. All health professionals must adopt high safety standard of medical treatment, which is an important element for establishing causation in medical error.

10 EU health policy trends, a study prepared by LSE Health, February 2009, p. 24

11 Frischhut, M., Standards on quality and safety in cross-border healthcare in den Exter, A., (ed.), Cross-border health care and European Union law, Rotterdam, 2017, p. 60

12 Ibid.

$13 \quad$ Ibid., p.63.; Vojković, op. cit., note 1, p. 569

14 Available at: [http://ec.europa.eu/health/], accessed on 10. June 2020

15 Available at: [http://ec.europa.eu/health/ph_overview/co_operation/mobility/docs/health_services_ co1008], accessed on 10. June 2020 
Directive 2011/24/EU of the European Parliament and of the Council of 9 March 2011 on the application of patients' rights in cross-border health care envisages the provision of safe, high quality, efficient and quantitatively adequate health care to citizens on their territory. Therefore, it derives that high quality should be interpreted on the basis of the case T-177/13. ${ }^{16}$ Although it might be unclear as to what high level in health care protection refers to in terms of the quality of care, it should be emphasised that high level does not imply "the highest level", as recently confirmed by the General Court. The Directive provides rules for facilitating the access to safe and high-quality cross-border health care and promotes cooperation on health care between the Member States in full respect of national competencies in organising and delivering health care. ${ }^{17}$ The rights of patients to receive health care in other Member States of the EU depend upon both the individual rights and the social rights.

In the matter of resolving medical malpractice cases, according to the 2008 study of the Council of Europe, the patients' prefer the following: future prevention (deterrence effect), restoration of a violated right, financial compensation, explanation and apology. ${ }^{18}$

\section{CAUSATION}

Medical error occurs when the treatment was not in line with the required and generally accepted professional quality standard. Hence, (medical) error may be defined as a (medical) violation of the duty of care or a consequence of manifestly negligent conduct. ${ }^{19}$ In that case, causation needs to be questioned. ${ }^{20}$ Errors in the diagnosis and treatment are considered the necessary preconditions for criminal liability. However, even if they are proved, that is still not enough for conviction.

16 Case T-177/13 TestBioTech and Others v. Commission [2016] ECR $I-736$. The high level does not necessarily, in order to be compatible with that provision (i.e. TFEU Article 168 (1)) have to be the highest that is technically possible..."

17 Directive 2011, Art. 1

18 Turković, K.; Roksandić Vidlička, S.; Maršavelski, A., Recommendation on alternative dispute resolution in medical liability in Council of Europe member states, Book of proceedings of the 18th World Congress on medical law, 2010. in Turković, K. et al. (eds.)., Hrestomatija hrvatskog medicinskog prava, Pravni fakultet Sveučilišta u Zagrebu, 2016, p. 886; Physicians in many states in Europe provide services according to the gold standard following the protocols of proceeding, however we cannot avoid the question of whether the standard can really be fully applied if the conditions are not entirely appropriate (equipment, organisation, personnel). Roksandić Vidlička, op. cit., note 3, p. 265

19 Mrčela, M.; Vuletić, I.: Granice nehajne odgovornosti za kazneno djelo nesavjesnog liječenja, Zbornik radova Pravnog fakulteta u Splitu, vol. 54, no.3, 2017, p. 690

20 Watson, K., Kottenhagen, R., Patients' Rights, Medical Error and Harmonisation of Compensation Mechanisms in Europe, European Journal of Health Law, vol. 25, no. 1, 2017, p. 10 
The prosecutor must prove two additional liability requirements: the occurrence of consequences and a causal nexus between the errors in treatment and consequences. ${ }^{21}$ The classification of error is important for discovering its cause and detecting the most common problems in the provision of health care services, and it has a positive role, i.e. it serves to provide guidelines for improving the quality of health care services and the overall organisation of the health care system. ${ }^{22}$ The court is required to conduct an ex ante evaluation, i.e. to imagine being in the same space-time circumstances in which the facts under examination took place. ${ }^{23}$ Ex ante evaluation must consider all diagnostic and therapeutic hypotheses formulated with respect to knowledge of the true pathological state/condition, deduced ex post from the data collected after the event in question, since only such an evaluation can reflect the aspects of evaluation and decision-making existing in the space-time conditions in which health care professionals were working. ${ }^{24}$

The central issue of medical liability is to establish causation, since liability exists only if the error of the physician caused harm to the patient's health. ${ }^{25}$ There must be a causal link or causation between the act performed by the physician or his/her omission and the resulting consequence. It is necessary to establish that the consequence resulted from the act/omission of the physician, i.e. that the cause of the consequence was the act or omission of the physician. Causation has an objective nature and precedes guilt, hence, if there is no causal link, no guilt can be established. Causation issues generally occur in result crimes ${ }^{26}$, i.e. those acts which are considered to be completed only by the occurrence of a specific consequence contained in the definition of the criminal offence and in the case of derivative omission ${ }^{27}$ offences whereby the guarantor is legally bound to avert the occurrence of the consequence. The existence of a causal link between the physician's act/omission and a consequence that occurred in the form of an injury to the patient's life, body, health or other legal good is often called into question due to medical solidarity, even

21 Vuletić, I., Medical Malpractice as a Separate Criminal Offense: a Higher Degree of Patient Protection or Merely a Sword Above the Doctor's Heads? The Example of the Croatian Legislative Model and the Experiences of its Implementation, Medicine, Law and Society, vol. 12, no. 2, 2019, p. 44

22 Roksandić Vidlička, S.; Ćepulić, E.; Babić, T., Scandinavian model of insurance from medical error - can it live in framework of Croatian legislative, Zbornik radova, 1. Kongres pravnika u zdravstvu, 2008, p. 90

23 Ferrara et al., op. cit., note 2, p. 546

24 Ibid.

25 Zečević, D.; Škavić, J., Kaznenopravna i gradanskopravna odgovornost liječnika - teorija i praksa, Medicinska naklada, Zagreb, 2012, p. 18

26 Bohlander, M., Principles of German Criminal Law, Oxford, Portland, Oregon, 2009, p. 40

27 Ibid. 
in situations of extremely gross errors committed by the physician. ${ }^{28}$ The establishment of causation is a rather complex element of the evidentiary procedure, because a medical intervention conducted lege artis does not always guarantee the expected outcome. In other words, the occurrence of consequences does not imply the existence of a criminal offence. Because of the uncertain etiology of some health conditions or different reactions of patients to certain drugs and treatment procedures, causation is very difficult to determine in some cases. There are cases where it is not possible to determine the causal relationship between the medical negligence and the injury because the injury resulted from a series of causes. Therefore, the mere existence of a harmful consequence does not imply the existence of causation and liability of the physician, since the consequence can occur independently of the error made. ${ }^{29}$

Medical error should be distinguished from the subsequent consequence. A subsequent consequence is an unwanted outcome of a medical procedure that occurs despite a medically correct and timely procedure performed using the correct equipment and treatment (drugs, chemicals), with optimal organisation of work. Therefore, if unforeseen circumstances - subsequent consequence, which cannot be imputed to the accused, occurred during the treatment, then his/her acts should be assessed within the domain of unforeseen circumstances. ${ }^{30}$ It should be noted that not every adverse event or harmful outcome should be automatically identified as a medical error. ${ }^{31}$ In order to make such identification, all circumstances leading to an adverse outcome need to be clearly established through professional medical expertise. Although it usually implies something unwanted, unfavourable and negative, the mere existence of a subsequent consequence should not be $a$ priori understood as a product of a medical (professional) error, malpractice and/ or negligence, nor should it prejudice one's guilt. Furthermore, it should not be understood as a safe solution that unconditionally leads to the release of any responsibility (moral, civil, criminal) for its occurrence.

28 Simonović, B., Teret dokazivanja dijagnostičkih grešaka i njihovih posledica, Glasnik prava, 6, 1997, p. 29

29 Supreme Court of Croatia, IV Kž 52/2004-2 of 30 June 2004

30 Roksandić Vidlička, S., Aktualna pitanja pojedinih kaznenih djela protiv zdravlja ljudi u svijetlu donošenja nacrta izmjena hrvatskog kaznenog zakona, Godišnjak Akademije pravnih znanosti 1/2010 in Turković, K. et al. (eds.), Hrestomatija hrvatskog medicinskog prava, Pravni fakultet Sveučilišta u Zagrebu, 2016, p. 825

31 Petrović, O., Treba li odlučivati između komplikacije i stručne pogreške?, Liječnički vjesnik, vol. 135, 2013, p. 101 


\section{CONTINENTAL LAW LEGAL SYSTEM}

Two legal systems co-exist across the European continent. The first and the most common one is continental law, while the second one is common law.

A comparative overview of the criminal codes of the majority of European countries shows that there are two main approaches to regulating medical errors: through general criminal offences against life and body (typical for Western European countries) or by prescribing separate criminal offences referred to as medical malpractice which are designed for the work domain of medical professionals (typical for Eastern European countries, such as the countries of former Yugoslavia and Ukraine). ${ }^{32}$

One approach is to treat every medical procedure as a type of bodily injury and, therefore, qualify cases of medical malpractice as criminal offences of causing bodily harm to a patient. German law, which considers the cases of medical malpractice under $\$ 223$ regulating the general crime of causing bodily harm, is a typical example of such legislative approach. The practical consequence of such an approach is that every medical procedure partially constitutes actus reus of the criminal offence, unless the defendant can prove the existence of grounds for the exclusion of that actus reus. This approach is common in Western European countries. However, it can lead to significant practical difficulties in the cases involving elective medical procedures (e.g. plastic surgery). ${ }^{33}$

Another possible approach for a certain legislator is to prescribe medical malpractice as a separate crime (in a separate chapter of the criminal code). This kind of regulation allows the specification of details of medical malpractice, the legal grounds of criminal liability and the appropriate penalty. A practical consequence of this model is that not every medical procedure constitutes actus reus of a criminal offence, but only the procedures characterised by special circumstances (e.g. only the ones deviating from the medical standards). Therefore, the criminal domain is even narrower than in the first model. This criminal offence emphasises a stronger deflection from the physician`s objective liability. ${ }^{34}$ A typical example of such an approach is Croatia, since the Croatian Criminal Code provides for a special offence of negligent treatment (Art. 181). ${ }^{35}$

\footnotetext{
32 Vuletić, op. cit., note 21, p. 40

33 Ibid., p. 42

34 Turković, K.; Roksandić Vidlička, S., Reforma kaznenog zakonodavstva u području zdravstva - Kaznena djela protiv zdravlja ljudi de lege ferenda, Zbornik radova Aktualnosti zdravstvenog zakonodavstva i pravne prakse, Novalja, 2011. in Turković, K. et al. (eds.), Hrestomatija hrvatskog medicinskog prava, Pravni fakultet Sveučilišta u Zagrebu, 2016, p. 869

35 Vuletić, op. cit., note 21, p. 42
} 
In the continental law system, the objective determination of the act of committing the criminal offence primarily requires the identification of the medical procedures in question and determining whether they are appropriate and regular from the standpoint of the medical profession according to objective criteria. Even though the legal theory and the judiciary apply different theories to determining causation, objective imputation presents itself as the most appropriate theory in this case. ${ }^{36}$

Since the theory of equivalence had certain shortcomings, e.g. its broadness, as it takes into account even the distant and irrelevant causes, a new theory of adequacy was introduced in the second half of the XIX century. The theory of adequacy does not perceive natural causation as sufficient because the outer consequence must occur as an adequate or a typical consequence of the conduct of the accused. ${ }^{37}$ In other words, human actions must be experientially appropriate in order to lead to a specific consequence, because otherwise, there is no causation. The theory of objective imputation emerged in the XX century in the German doctrine that followed the theory of adequacy, and although it has not been completely implemented by the common law, it has, gradually, assumed primacy in the German doctrine. According to this theory, an act can be perceived as the cause of the consequence when it jeopardises the object of an offence, and the harmful event occurs as a consequence. The first condition is that the perpetrator exceeds the limits of the permissible risk, thus endangering the object of the action. ${ }^{38}$ For the existence of criminal liability, it is necessary to establish that a harmful event or risk, created by the violation of due diligence, resulted as a consequence. In this sense, the theory of objective imputation should be applied as dominant. This means that the court must ask the expert witness whether the same consequence would have occurred if the perpetrator had applied the necessary internal and external due diligence. Internal due diligence represents a prediction of the risk to the protected legal good and external due diligence presents the adjustment of further conduct to the previous knowledge of a dangerous situation. ${ }^{39}$ The theoretical learning about the objective imputation is reduced to determining specific constellations in which objective imputation of consequences is excluded. Such objective imputation will be excluded in cases of remote and legally irrelevant actions, if taking action reduces the risk of violation or endangerment of the protected legal good,

\footnotetext{
36 See more in Novoselec, P.; Bojanić, I., Opći dio kaznenog prava, Zagreb, 2013, pp. 150-158

37 Munivrana Vajda, M.; Ivičević Karas, E., Criminal law, Supplement 57 Croatia, International Encyclopedia of Laws, 2016, p. 57

38 Martinović, I., Problem uzročnosti u kaznenom pravu, Hrvatski ljetopis za kazneno pravo i praksu, vol. 19 , no. 1, 2012, p. 84

39 Mrčela; Vuletić, op. cit., note 19, p. 694
} 
if the risk remains equal or does not increase in a legally relevant manner, if the consequence would have occurred even if the perpetrator had complied with the regulations, if the consequence was the result of an unpredictable external factor, and if the perpetrator acted contrary to a legal norm and caused the consequence, but not the one which the violated legal norm is intended to avert. ${ }^{40}$

A problem can arise when it is not possible to determine with absolute certainty whether the consequence would be safely remedied if the necessary attention was attributed. This also raises the question of the required standard of certainty in this regard. The Croatian literature advocates the standpoint that a high degree of probability or probability in line with certainty is required. According to the prevailing opinion in the German literature, in accordance with the in dubio pro reo rule, one must be acquitted whenever the absence of a consequence cannot be established with a probability in line with certainty. This rule is supplemented by the theory of increased risk (Risikoerhöhungslehre) according to which it is necessary to prove that the violation of due care has led to a significant increase in the risk of endangering the object of action. If such an increase has occurred, then it is enough for the omission to be considered causal. In this sense, the in dubio pro reo rule should be used only in a situation where, with a probability in line with certainty, it cannot be determined whether the negligent conduct has led to an increase in risk at all. ${ }^{41}$

In addition, the judicial practice in continental law has been increasingly adopting the concept of prescriptive alternative behaviour. According to a judgment of the Bjelovar County Court ${ }^{42}$ in Croatia, a surgeon at a hospital lacking the necessary surgical equipment was released from liability for a patient's death; he was accused of failing to transfer the patient to an appropriate specialised hospital in time due to a high level of probability of the patient's death. In this particular case, the expert witness established that the accused surgeon had committed malpractice because he failed to consult a cardiac surgeon or a vascular surgeon and refer the injured person to a specialised facility under a slight suspicion of aortic rupture, since such injury could not be successfully treated at the surgeon`s hospital due to the lack of adequate equipment. However, the Court of Appeal accepted the claim that this was not the case of defendant's omission. ${ }^{43}$ The findings derived from the

\footnotetext{
$40 \quad$ Martinović, op. cit., note 38, p. 93

41 Mrčela; Vuletić, op. cit., note 19, p.695

42 Judgment of the Municipal Court in Bjelovar, K-105/2009 of 14 September 2011. Roksandić Vidlička states that prescriptive alternative behaviour is often used in jurisprudence in Croatia, and she emphasises the importance of determining causality for the final outcome of criminal proceedings. Roksandic Vidlička, op. cit., note 3, p. 261

43 Judgment of the County Court in Bjelovar, KŽ-443 / 2011-3 of 16 February 2012
} 
presented evidence do not suggest a reliable conclusion that the deterioration of the victim's health and death was a consequence of these procedures. In fact, it is evident from the findings and the expert opinion of the School of Medicine in Zagreb that the mortality resulting from the aortic surgery was up to $40 \%$, and that the $60 \%$ chance of survival does not provide a solid basis for the causal link between the surgeon's omission and the resulting consequence, since it cannot be reliably ruled out that the same consequences would not have occurred if the injured person had been transferred to a specialised hospital immediately after the accident. In addition, it is disputable whether the patient would die during the operation because of the aorta rupture. In this case, it was rather challenging to prove whether the consequences caused by acting non lege artis could be imputed to the surgeon if the same consequences would have occurred provided that he had acted lege artis. The court accepted that the death in this particular case could not be excluded even if the injured person had been transferred in timely manner, since the survival rate in such cases is statistically only 3\%, while in $97 \%$ cases of aortic rupture caused by traffic accidents the patients are proclaimed dead on arrival. In other words, if the surgeon had acted lege artis, the possibility of a fatal outcome would not be excluded, but there would be at least a small possibility for the patient to survive. ${ }^{44}$ In such cases, the German courts have also decided on acquittal by relying on the procedural principle of in dubio pro reo, which is accepted by some legal theoreticians, although they differ in the degree of the required probability. ${ }^{45}$

On the contrary, the Court of Appeal in Brussels convicted the physician because, due to his malpractice (lack of due care and failure to act lege artis), the patient lost a $90 \%$ chance of survival. However, the Court of Cassation vacated the judgment at the first instance because the court could not establish causation between the malpractice and the death of the patient in the remaining $10 \%$ of cases where negligent treatment did not result in death. The court concluded that, since no "certain" causation was established between the medical error and the patient's death, there was only a "loss of chance for survival", so the physician cannot be held liable. ${ }^{46}$ In criminal law, a physician cannot be convicted if the patient loses

\section{Ibid.}

45 However, in above-mentioned example, the probability of survival was higher than the probability of death, which may lead to the conclusion that the surgeon needs to be liable for the patient's death. Novoselec, P., Sudska praksa, Hrvatski ljetopis za kazneno pravo i praksu, vol. 19, no. 2, 2012, p. 937

46 Court of Appeal in Brussels, 27 February 1974, De Verz., 1974, 637 cited in Callens, S., Medical Civil Liability in Belgium. Four Selected Cases, European Journal of Health Law, vol. 10, no. 2, 2003, p. 122. In Belgian civil law, however, the compensation for the "loss of the chance for survival" is possible, because it is easier for the patient to prove a causal link between the error and the injury. Dias Pereira, G. A., Existing challenges in medical liability: causation, burden of proof and informed consent, The ev- 
his "chance of survival", but he/she may be convicted if causation is established between the physician's medical error and the injury or death of the patient. Although the jurisprudence of the European states generally accepts the theory of equivalence, it still raises a question whether a criminal court can convict a physician if the harm that the patient suffered is merely considered a "loss of chances of being cured or surviving". Hence, according to the theory of increasing risk, the perpetrator would be liable for the consequence, because a threat to a legal good can only be tolerated within the limits of the permissible risk of the medical activity. An example is a surgeon who, by gross violation of the rules of profession, causes the death of a patient, but he/she is released from liability because a fatal outcome would have occurred even if the physician had acted lege artis. ${ }^{47}$

In this sense, the Committee on Judicial Opinions of the School of Medicine in Zagreb stated that it is inadequate to ground the expert's statement or the indictment on assumptions rather than on facts, and that it would be ethically and deontologically unacceptable for the doctors to deny any treatment options to the patient even if the patient is suffering from a serious incurable disease. They also concluded that it is absurd to criminalise infusion urography as the cause of death of a patient with a severe and incurable disease and attribute the fatal outcome to medical negligence. ${ }^{48}$

According to the theory of prescriptive alternative behaviour, the causal consequence must be realised through the risk arising from a medical error, which would not be the case if the same consequence would have occurred for the patient even if the physician had not made an error. The charges against the specialist doctor were dismissed, because he prescribed and administered additional 25 doses of radiation after 6 doses of treatment following the operation, which led to a subsequent consequence and sepsis, after which the patient died. All the evidence pointed to the fact that the deceased was treated in the usual and appropriate manner (lege artis) and the fatal outcome was due to the very nature of the disease, i.e. malignant cancer. Sepsis did not contribute to the fatal outcome, because there is no evidence that sepsis was directly related to additional radiation. If the radiation therapy that the physician ordered subsequently affected the patient's current condition, i.e. sepsis, it still cannot be claimed that the radiation therapy had been determined improperly, since the physician administered the relevant therapy in good faith

er-growing challenge of medical liability: national and European responses, Conference, Strasbourg, 2-3 June 2008, Council of Europe, 2009, p. 143

47 For more information on Legal Certainty see Vuletić, op. cit., note 21, p. 57

48 Municipal Court in Zagreb, KO-1169/02 cited in Zečević; Škavić, op.cit., note 25, p. 151 
and according to the best knowledge (lege artis). The fact that this additional therapy did not produce the expected results cannot be imputed to the physician. ${ }^{49}$

Although medical causation does not operate in line with the laws of physics, where a single cause always and unequivocally causes a certain effect, there are nevertheless some rules, general medical knowledge and experience based on which certain widely-known facts lead to a certain consequence. These are common knowledge to the extent that, for example, inflammation and perforation of the appendix likely cause peritonitis and consequently sepsis.

However, it is very difficult to establish direct causation, especially in the cases of cumulative causation when the consequence is caused by multiple simultaneous actions, each of which may result in the consequence. This occurs, for example, when the physicians work in a team. Common law, therefore, often uses hypothetical causation which requires the establishment of whether a medical error is generally appropriate to cause harm to a patient's health. In this regard, it is necessary to reduce the number of hypothetical theses and circumstances in terms of what would have happened if something else had happened. It is only necessary to prove the real circumstances, the actual causation, and to proceed solely from an established medical error. Therefore, the court must determine (with the assistance of an expert witness $)^{50}$ whether a specific medical error in the particular case caused, or was appropriate, or could have caused the resulting consequence. In the aforementioned process of proving causation, the existence of an error should be proved with absolute certainty, and the existence of a causal relationship between the error and the consequence should be proved with no less than a high degree of probability. In fact, in medicine, it is generally not possible to prove with absolute certainty that a particular error of a physician directly caused the consequence. ${ }^{51}$ In other words, the causal link between a medical error and an injury to the health or body, or the death of a patient exists only if the court, on the basis of the professional medical expertise, concludes that lege artis procedure would have saved or prolonged the life of the patient with a likelihood of probability in line with certainty. Probability in line with certainty means a degree of certainty that excludes reasonable doubt. ${ }^{52}$

\footnotetext{
49 Decision of the Municipal State Attorney in Split, DO-K-1601/01

50 Vuletić, op. cit., note 21, p. 48

51 Simonović, op. cit., note 28 , p. 31

52 Radišić, J., Odgovornost zbog pogrešne lekarske dijagnoze i nepreduzimanja potrebnih dijagnostičkih mera, Revija za pravo osiguranja, vol. 10, nNo. 1, 2011, p. 56. A free assessment of evidence means that the court can freely adjudicate a conviction based on certain presented facts, but it must not, on its own initiative, lower the standards required to reach a decision or go below the limit of "the highest degree of certainty". Martinović, op.cit., note 38, p. 91
} 
The existence of causation, with regard to the ex nibilo nibil fit principle, is a particularly challenging issue in the cases of derivative omission offences where the perpetrator does not act or take any action. Since there is no real causation in these cases, only a hypothetical one is possible where omission and consequence are correlated only if the omitted conduct would have eliminated the consequence. Instead of the hypothetical process of elimination, the judge should engage in the hypothetical process of addition and seek to find an answer to the question of what would have happened had the accused carried out the omitted conduct. ${ }^{53}$ If we want the consequence of the omission to be objectively imputed to the physician, the following three questions must be answered: "was there a legal obligation for the physician to avert the occurrence of the consequence", "would the compliance with those legal obligations effectively avert the occurrence of the consequence" and "was it possible in specific circumstances to prevent the occurrence of the consequence". ${ }^{54}$ In other words, the question arises as to what would have happened if the omitted action had been taken, or what would have happened if there had been no such breach of obligation. If the consequence would not have occurred, such omission must be imputed to the physician, and if the result would have occurred (if the answer is "the same"), the consequences will not be imputed to the physician. However, a certain degree of probability of avoiding the consequences is also required here, because a high degree of probability in line with certainty must be achieved. If such a degree of probability does not exist due to the principle of in dubio pro reo, the obliged action will not eliminate the consequence. ${ }^{55}$ Common law has been increasingly adopting hypothetical causation in the cases of medical omissions. Thus, in a case with two completely different diagnoses made by a physician within a short time of only a few days, where a recent death of a patient was caused by an illness which the physician failed to diagnose, hence omitting to prescribe the appropriate treatment, the Supreme Court in Croatia concluded that this sort of (lack of) care represents solid grounds for the suspicion that the physician had committed malpractice. It can be reasonably concluded that according to the presented evidence, the physician misdiagnosed the patient and prescribed the treatment that caused the aggravation of the patient's condition and, eventually, his death. ${ }^{56}$

In terms of the physician`s liability, it must be proved that the deterioration of the patient's health or the death of the patient is not the consequence of a natural, fatal course of the disease but of the medical error instead. The causation in court

\footnotetext{
53 Munivrana Vajda; Ivičević Karas, op. cit., note 37, p. 57

54 Bavcon, LJ. et al., Kazensko pravo, splošni del, Uradni list, Ljubljana, 2009, p. 180

55 For more information on pseudocausality see Novoselec; Bojanić, op. cit., note 36, p. 160

56 Supreme Court of Croatia, IV Kž-120/1991-2 of 18 December 1991
} 
proceedings is always proved with the assistance of expert witnesses, to whom the court refers several important questions generally summarised as follows: "what happened?"; "why did this happen?"; "was the event predictable?" and "could the event have been avoided?". ${ }^{7}$

The protocol of procedures for proving causation in medical cases should play an important role in the cases where those protocols have been adopted and implemented by each individual hospital, whereas in the cases where these protocols do not exist or the physician failed to comply with them, it is necessary to determine the applicable standards of care for conducting a particular medical procedure. ${ }^{58}$ A case conducted before the Rijeka County Court describes all acts or omissions that led to the occurrence of serious bodily injury, and the consequences that followed, including a life-threatening act and the amputation of one leg, including the medical standards of care that must be fulfilled. ${ }^{59}$ The first part refers to the fact that the surgeon failed to act with due care in accordance with the rules of the medical profession when selecting the appropriate treatment and performing the surgical procedure for appendicitis, namely he chose laparoscopic appendix removal surgery despite being aware that there is a risk of damage to the abdominal aorta. There were no organised specialist medical consultations with other surgical professionals in the shift, nor was he or the surgical team specialised for treating all surgical injuries, hence they failed to undertake all necessary measures to prevent and detect the injury in the process of preparation and implementation of the operation. The protocol of procedure was not applied in this case.

\subsection{Court and medical expert}

Medical experts are invited to deliver their expert opinions in criminal cases. Expert witnesses are in a very privileged position as they may provide a statement of opinion/evaluation as evidence, unlike other witnesses who can only give evidence of fact. Whichever party invites the experts, their duty is clear - to provide impartial and objective evidence for the court and not for the party that invited them. If

57 Altamura, M. et al., The legal status of Uncertainty, Nat. Hazards Earth Syst. Sci., no.11, 2011, p. 803

58 Even so, the patients in Norway find it difficult to prove the physician's responsibility for negligent treatment. Most crime reports are dismissed or the patient loses the case. This is particularly true for criminal liability, because even a charge for a serious crime will be difficultly accepted by the court. Sonederland, K., Medical Malpractice-the Legal Situation in Norway, European Journal of Health Law no. 3, 1996, p. 177.; Vojković, op. cit., note 1, p. 570

59 Roksandić Vidlička, S.; Pražetina Kaleb, R., Utvrdivanje pravnog kontinuiteta i tumačenje elemenata bića kaznenog djela nesavjesnog liječenja, Zbornik radova s međunarodnog kongresa, 1. Kongres KOKOZA i 3. Hrvatski kongres medicinskog prava s međunarodnim sudjelovanjem“, Rabac, 2019, p. 314-315 
an expert witness evaluation is to be used, it must be disclosed to the prosecution. The prosecution, however, is under an obligation to disclose all its evidence to the defence. ${ }^{60}$

Unlike other countries, where the opinion of at least two experts is required, Croatian system only requires one assessment. Additional opinions by the same or different medical experts are warranted only in situations where the initial opinion has been ambiguous or contradictory. Criminal liability will be excluded if there is a disruption of causation. ${ }^{61}$

In principle, it can be said that determining the type of guilt in medical cases almost always requires expert evaluations, because only a medical expert will be able to assess with competence whether or not a certain consequence was foreseeable (or should have been foreseeable) to a doctor in a given situation, or if the doctor was aware (or should have been aware) of the inadequacy of a certain diagnostic or therapeutic procedure. ${ }^{62}$ In accordance with the iura novit curia principle, Croatian law operates under the premise that the court knows the law, hence it does not require interpretative assistance in resolving legal issues. Assistance is required only for the determination of facts in the fields where the court does not have respective expertise, which, in medical cases, implies a mandatory engagement of medical experts. Accordingly, it is important for the court to establish clear parameters for the medical expert assessment and to ensure that the relationship between the judge and the medical expert does not cross the line of expert assistance to the court: the medical experts should not de facto write the decision for the court through their evaluation. Therefore, the court must limit the expert's role to providing only the data which are legally relevant for deciding liability. ${ }^{63}$ Judges usually incorporate the verbatim evaluations of the medical experts into their decision, and thus the medical experts indirectly help draft the court decision, which is not only inappropriate, but also questionable from the perspective of the constitutional competences of the judiciary. This dependence on a medical expert's evaluation raises another issue, which is the near indemonstrability of the legal standard of criminal causation between a doctor's error and the subsequent consequence for the health or life of a patient. In many decisions, the court accepts the findings of the medical expert, even though they may not seem generally

\footnotetext{
60 Papagiannopoulos, K., The ideal and impartial medical expert: tips and tricks for a safe medicolegal practice, J Thorac Dis. vol. 11, no. 7, 2019, p. 1010

${ }^{61}$ Vuletić, op.cit., note 21, p. 45

62 Ibid., p. 46

63 Novoselec, P., Opći dio kaznenog prava, Osijek, 2016, p. 22
} 
convincing. Consequently, medical experts once again have a decisive impact on the type (and quality) of the judgement. ${ }^{64}$

The assessment of credibility of the expert report and the decision on which of several similar expert reports will be the basis for determining the decisive circumstances is made exclusively by the court on the principle of free assessment of evidence. The court is obliged to reasonably explain its assessment of evidence as to which evidence it has accepted and which it has not, and why it has assessed the evidence in a certain way. The court is not obliged to accept the expert's finding and opinion, but it must have more substantial reasons for that than in relation to other evidence. The court must not simply dismiss the expertise without providing proper reasoning. Therefore, if the parties to the proceedings dispute the mechanism of occurrence of the injury, an expert opinion will be necessary. And if the fact of the injury is not disputable, then no expertise is required. ${ }^{65}$

In determining and evaluating the expert's findings and opinions, the following guiding questions are important ${ }^{66}$ :

1. Has there been a violation of the standard of care, what does it consist of and was it obvious by the standard of an average doctor of similar standing as the accused? 2. Where does the standard of care derive from and does the established practice deviate from good practice in this respect?

3. Did the act (omission) cause the consequence or was the causation disrupted? 4. If the concurrent causes were also involved, was the act (omission) of the accused the one that significantly increased the risk of consequences?

5. Did the doctor recognise or should have recognised the risk at the moment of (not) taking the action, according to the criteria of the average doctor of similar standing as the accused?

6. At that time, was it foreseeable or should it have been foreseeable for the doctor that the consequences could occur according to the criteria of the average doctor of same standing as the accused?

\section{COMMON LAW LEGAL SYSTEM}

The common law legal system exists in England, the United States and other countries colonised by England.

\footnotetext{
${ }^{64}$ Vuletić, op. cit., note 21, p. 50

65 Mrčela; Vuletić, Liječnik i kazneno pravo, Zagreb, 2019, pp. 98-99

66 Ibid., p. 23
} 
By analysing the current legal system of the United States, it has been noted that the most important reform of the physician liability system for malpractice in the United States began in 2005 by the adoption of the Health Act, whose primary aim is to regulate medical malpractice litigation. ${ }^{67}$ Considering the special working conditions of medical staff and the largely humanistic nature of their work, certain legal systems give precedence to civil law protection. This is particularly notable in the countries where health care is largely privatised. A typical such example is the USA, where medical errors are almost never treated under criminal law protection but dealt with in civil litigation for the compensation of damages in $90 \%$ cases. Medical errors are mostly resolved through a developed settlement system. ${ }^{68}$ Even though this paper analyses only criminal law, USA law is an exception because it settles medical cases under civil law. The Health Act introduces pre-trial screening panels that consist of physicians, lawyers, and patients' representatives, and in a particular case where a doctor is sued for malpractice, they try to determine whether there is a deviation from the standard of due care $e^{69}$, whether there is a causal link between the act or omission of a physician and the resulting adverse consequences, whether there is a liability of the physician or a shared responsibility of the physician and the patient. The pre-trail screening panel can result in accepting the panel's decision or making a suitable arrangement among themselves, or the patient may decide to go to court. In case the patient does not accept the panel's decision or does not reach an agreement with the physician, and decides to take legal action, then all that is presented before the pre-trail screening panel can be used as evidence in the court proceedings, and the patient may be required to deposit a court fee, which discourages them from taking legal action. In addition, due to the complexity of the matter, special medical courts have been established because the judges who deliberate in these cases must specialise in medical law. Alternative dispute resolution, arbitration and mediation methods have also been introduced. ${ }^{70}$ Also, the common law, especially in litigation, raises the question of using a doctor's apology as evidence of his liability, despite the fact that an apology can only be an expression of empathy intended for a grieving family. ${ }^{71}$ The most

67 Health Act, 354. Available at [http://thomas.loc.gov/cgi-bin/query/F?c109:1:./temp/-c109831jHe:e1001], accessed on 10. June 2020

68 Vuletić, op.cit, note 21, p. 40

69 For more information on due care as an element of guilt see Kurtović Mišić, A.; Sokanović, L., Namjera kao stupanj krivnje u počinjenju kaznenih djela zdravstvenih radnika, Zbornik radova s međunarodnog simpozija „2. Hrvatski simpozij medicinskog, prava”, Vodice, 2016., p. 133

70 Gregory, C.M., Recent Developments in Health Care Law: Note: Capping Noneconomic Damages in Medical Malpractice suits is not the Panacea of the "Medical Liability Crises", WM. Mitchell L. Rev., vol. 31, no. 3, 2005, p. 1031

71 The legal nature of apology is discussed within the rules of evidence in the Anglo-American legal system; it is defined broadly as a statement made by the perpetrator to his victim in order to be under- 
recent case that has drawn attention to the issue of legal implications of an apology occurred in California in March 2013 when the oral surgeon Dr. Steven Paul removed wisdom teeth of Marek Lapinski, a twenty-four-year-old programmer in good health. Mr. Lapinski stopped breathing during a routine operation and died three days later at the hospital. Dr. Paul, who was present at the hospital at the time of death, apologised to the mother of the deceased patient. An autopsy determined that the cause of death was an overdose of anaesthesia (propofol), so the Lapinski family filed a lawsuit against Dr. Paul for medical negligence. ${ }^{72}$

In English law, the physician`s liability is also based on the criteria that there is no guilt for negligence, if the physician acted in accordance with a standard of care accepted by the competent medical authorities for certain specialisations. The increase of disputes over medical negligence in the UK has prompted a review of the clinical negligence liability system and has been discussed in the case of $R . v A d o-$ mako, Bolitho $v$ City of Hackney HA, Marriot $v$ West Midlands HA, Pearce v United Bristol NHS Trust and Chester in Afshar. ${ }^{73}$ In particular, the English judicature emphasises that clinical practice standards are not static, so the judiciary is allowed to apply a wide margin of appreciation, which leads to a case where the existing system is replaced with a new system of redress. In 1994, a case of $R . v$ Adomako occurred. ${ }^{74}$ The defendant, Mr. Adomako, was an anaesthetist. He participated in an eye operation which required that the patient be put under general anaesthesia. During the operation, and under Mr. Adomako's supervision, a crucial tube disconnected from the ventilator and the patient suffered a fatal cardiac arrest. Mr. Adomako was convicted of manslaughter by breach of duty. Mr. Adomako was unaware of the disconnection and was convicted of manslaughter. This conviction was upheld by the House of Lords. In the cases of manslaughter by criminal negligence involving a breach of duty, it is a sufficient direction to the jury to adopt the gross negligence test. If such a breach of duty has been established, the next question is whether that breach of duty caused the death of the victim. If so, the jury must go on to consider whether that breach of duty should be characterised as gross negligence and therefore as a crime. This will depend on the severity of the breach of duty committed by the defendant in all the circumstances in which the defendant was placed when the breach occurred. The jury will have to consider

stood as an apology, or at least an expression of remorse or regretting something done. Helmreich, S. J., Does "Sorry" Incriminate? Evidence, Harm and the Protection of Apology, Cornell J.L. \& Pub. Pol'Y, vol. 21, no. 2, 2012., pp. 567-570

72 Gailey, L., "I'm Sorry" as Evidence? Why the Federal Rules of Evidence Should Include a New Specialized Relevance Rule to Protect Physicians, Def. Counsel J., vol. 82, no. 2, 2015, p. 172

73 See more in McHale, J.V., Medical Malpractice in England - Current Trends, European Journal of Health Law, vol. 10, no. 2, 2003, p. 136

74 R. v Adomako (1994) 3 W.L.R. 288 
whether the extent to which the defendant's conduct departed from the proper standard of care incumbent upon him, involving as it must have done a risk of death to the patient, was such that it should be judged criminal. The essence of the matter which is supremely a jury question is whether having regard to the risk of death involved, the conduct of the defendant was so bad in all the circumstances as to amount to a criminal act or omission in their judgment.

In 1997, the Bolitho $v$ City of Hackney HA case concerned a 2-year-old child who was being treated for respiratory problems and who suffered two cases of acute air deficiency in one day. In both cases, the department nurse summoned the doctor, but the doctor did not arrive. ${ }^{75}$ Later that day, the baby stopped breathing, causing cardiac arrest, and, while resuscitated, sustained severe brain damage. The court concluded that it was the doctor's negligence because he was not present to undertake the necessary measures and the evidence was contained in the fact that even if the doctor had been present at the time of the cardiac arrest, brain damage would have continued until the doctor intubated the patient. ${ }^{76}$ The test of expertise is the customary standard of care of an average skilled physician. A physician does not need to possess the highest level of expert skills at the risk of being found negligent, but it is sufficient that he/she exercises the customary degree of skills and prudence of an average competent physician. ${ }^{77}$

In addition to exercising reasonable care, a physician is obliged to keep up with new developments in their respective field. ${ }^{78}$ In the ruling, the court emphasised the need for any body of medical opinion to be reasonable and responsible.

The limits of liability set in the Bolitho case were upheld in 1999 in the case Marriot $v$ West Midlands HA where Mr. Marriott suffered head injuries after he fell in his home. He was taken to hospital and was released for home care the following day after undergoing a brain CT. However, his condition did not improve, and he was examined by a general practitioner eight days after being discharged from the hospital, where he was subjected to neurological tests that showed no abnormalities. Four days later, when his condition worsened, Marriott was admitted to the hospital where he underwent surgery for skull fracture and internal bleeding. Ultimately, he was left paralysed with a speech disorder. Liability in English tort law is determined by the "but-for" test. The test asks, "but for the existence of X, would Y have occurred?" If the answer is yes, then factor X is an actual cause of

\footnotetext{
75 See more in Vojković, op. cit., note 1, p. 583

76 McHale, op. cit., note 73, p. 137

77 Nys, H., On Medical Liability in Council of Europe Member States, A comparative study of the legal and factual situation in Member states of the Council of Europe, Strasbourg, 2005, p. 8

78 Ibid.
} 
result Y. For the existence of negligence, it is necessary to establish that: (i) the person was obliged to provide care; (ii) the duty of care has been violated, (iii) the direct consequence of that injury has been caused by legally recognised damage. ${ }^{79}$ In the case of concurrent causes, causation can be established if the breach of duty materially contributed to the injuries. However, in many cases the cause of injury is unclear, which led the House of Lords to decide that the material increase in the likelihood of injury was not enough for establishing causation. In general, the "but-for" test can be perceived as a filter to exclude the acts that had no effect on the outcome. In case there are two unrelated potential causes and both could have caused the injury, causation depends on the nature of the events and the order in which they occurred. It is also possible that an act of another person, without which the damage would not have occurred, occurs between the physician's negligence and the patient's injury. Exceptionally, the causation chain can be interrupted if an independent cause starts a new chain of causation, irrespectively of the conduct of the accused.$^{80}$ Hence, the English judiciary advocates the standpoint that a medical error can interrupt the causation in case of novus actus interveniens, i.e. an action or event that represents an "extraordinary", "powerful" or "so potent" contribution to the cause. ${ }^{81}$

In Scotland, which, despite being part of the UK, has its own separate legal system, the model of health care liability is very similar to the one adopted in England and Wales. This is especially true in case of medical liability, so the issues of standards of medical care and causation are dealt with in the same way as in the English law. However, Scottish judicature sometimes exhibits innovation in particular areas of medical liability, so in the cases of damage caused by the treatment and/or diagnosis, the court will almost always invoke the formulation of the Hunter $v$ Hanley test. In Hunter $v$ Hanley test, in order to determine a physician's responsibility, three facts need to be established: first and foremost, common and normal practice must be analysed; secondly, it must be proved that the defendant did not adopt this practice, and thirdly, it is crucial to find that the doctor acted in a way opposite of any expert possessing average skills. ${ }^{82}$

79 The rules of civil procedure in England and Wales allow the initiation of proceedings for damages in medical negligence cases within 3 years from the date of the act/omission or within 3 years from the date the victim became aware of possible medical negligence. Bryden, D.; Storey, I., Duty of care and medical negligence, Continuing Education in Anaesthesia, Critical Care \& Pain, vol. 11, no. 4, 2011, p. 124

80 Munivrana Vajda; Ivičević Karas, op.cit., note 37, p. 57

81 For more information on causality in the case $R v$ Cheshire see Ormerod, D, Smith and Hogan Criminal Law,2011, p. 69.; Carstens, P., Medical negligence as a causative factor in South African criminal law: novus actus interveniens or mere misadventure? S. Afr. J. Crim. Just. vol. 19, no. 2, 2006, p. 197

82 Blackie, W. G. J., Medical Negligence in Scotland, Eur. J. Health L., vol. 3, no. 2, 1996, p. 136 


\section{CONCLUSION}

Common law research shows that criminal common law determines causation by deciding whether a physician's act/omission constitutes a medical error or subsequent consequence in terms of guilt or negligence, and not whether a violation of prescribed protocols or procedures has resulted in the deterioration of health. For example, in the case of liability for malpractice, it is necessary to prove that the deterioration of the patient's condition did not arise from the nature of the primary disease or injury but rather from the act/ omission of the physician. However, the research conducted indicates that public prosecutors' offices and courts have many difficulties in establishing the causal link between a physician's act/omission and a detrimental effect on a patient's health. These issues occur because the question arises as to whether the perpetrator used the necessary internal and external due care, or, when it is not possible to determine with certainty, whether the consequence would have been safely eliminated, if the reasonable and competent degree of skill had been taken. ${ }^{83}$

As a result, a patient must show that he suffered harm because of the physician's fault which can consist of negligence, lack of skill, improper information. When defining reasonable care, the conduct of a physician is compared with that of the bonus medicus or the standard of the prudent and competent physician with the typical qualities and skills, placed in the same circumstances as the defendant physician (objective standard of care). ${ }^{84}$ The deviation from the professional standard will be considered a fault for which a physician can be held liable, even if they regards their actions as reasonable. ${ }^{85}$

All documents mentioned in this paper that have been adopted by the European Union and the Council of Europe determine the standards of health care that must be provided. Even though it is not necessary to provide the highest level of health care protection, all available means must be taken in consideration in a specific state, city or hospital.

This raises the issue of the required standard of certainty and standard of quality. Is it sufficient to have a high degree of probability or probability that is in line with certainty (overwhelming certainty) ${ }^{26}$ Causation does not exist if the consequence would still occur despite providing treatment with due diligence in accordance with the medical standard of care.

\footnotetext{
83 Vojković, op. cit., note 1, p. 577

${ }_{84}$ Nys, op. cit., note 77, p. 3

85 Ibid.

86 Vuletić, op.cit, note 21, p. 56
} 
In order to avoid confusing causation with guilt, it would be preferable to adopt the theory of objective imputation that follows the theory of adequacy, as a legal standard for causation, in criminal and civil liability in medicine, because it analyses several possible causes that could be in close or remote connection with the resulting consequence, i.e. said theory considers as relevant only the legal causes that result in a harmful event through the violation of due diligence. After all, this is also in line with the established medical treatment protocols, since acting contrary to the prescribed protocols typically leads to a certain harm to the patient's health.

\section{REFERENCES}

\section{BOOKS AND RESEARCH PAPERS}

1. Altamura, M. et al., The legal status of Uncertainty, Nat. Hazards Earth Syst. Sci., no.11, 2011

2. Bavcon, LJ. et al., Kazensko pravo, splošni del, Uradni list, Ljubljana, 2009

3. Blackie, W. G. J., Medical Negligence in Scotland, Eur. J. Health L., vol. 3, no. 2, 1996, pp. $127-141$.

4. Bohlander, M., Principles of German Criminal Law, Oxford, Portland, Oregon, 2009

5. Bryden, D., Storey, I., Duty of care and medical negligence, Continuing Education in Anaesthesia, Critical Care \& Pain, vol. 11, no. 4, 2011, pp. $124-127$.

6. Callens, S., Medical Civil Liability in Belgium. Four Selected Cases, European Journal of Health Law, vol. 10, no. 2, 2003, pp. $115-133$.

7. Carstens, P., Medical negligence as a causative factor in South African criminal law: novus actus interveniens or mere misadventure? S. Afr. J. Crim. Just. vol. 19, no. 2, 2006, pp. $192-211$.

8. Cohen, J.; Ezer, T., Human rights in patient care: A theoretical and practical framework, Health and Human Rights, vol. 15, no. 2, 2013, pp. 7 - 19.

9. Dias Pereira, G. A., Existing challenges in medical liability: causation, burden of proof and informed consent, The ever-growing challenge of medical liability: national and European responses, Conference, Strasbourg, 2-3 June 2008, Council of Europe, 2009

10. EU health policy trends, Study prepared by LSE Health, February 2009

11. Ferrara, S. D. et al., Malpractice and medical liability. European Guidelines on Methods of Ascertainment and Criteria of Evaluation, Int J Legal Med, vol. 127, no. 3, 2013, pp. 545 - 557.

12. Footman, K. et al., Cross-border health care in Europe, Denmark, 2014

13. Frischhut, M., Standards on quality and safety in cross-border healthcare in den Exter, A., (ed.), Cross-border health care and European Union law, Rotterdam, 2017

14. Gailey, L., "I'm Sorry" as Evidence? Why the Federal Rules of Evidence Should Include a New Specialized Relevance Rule to Protect Physicians, Def. Counsel J., vol. 82, no. 2, 2015, pp. $200-205$.

15. Gregory, C.M., Recent Developments in Health Care Law: Note: Capping Noneconomic Damages in Medical Malpractice suits is not the Panacea of the "Medical Liability Crises", WM. Mitchell L. Rev., vol. 31, no. 3, 2005, pp. 1031 - 1040. 
16. Helmreich, S. J., Does "Sorry" Incriminate? Evidence, Harm and the Protection of Apology, Cornell J.L. \& Pub. Pol'Y, vol. 21, no. 2, 2012, pp. 567 - 609.

17. Kurtović Mišić, A.; Sokanović, L., Namjera kao stupanj krivnje u počinjenju kaznenih djela zdravstvenih radnika, Zbornik radova s međunarodnog simpozija „2. Hrvatski simpozij medicinskog, prava“, Vodice, 2016

18. Martinović, I., Problem uzročnosti u kaznenom pravu, Hrvatski ljetopis za kazneno pravo i praksu, vol. 19, no. 1, 2012, pp. 75 - 104.

19. McHale, J.V., Medical Malpractice in England - Current Trends, European Journal of Health Law, vol. 10, no. 2, 2003, pp. 135 - 151.

20. Mrčela, M.; Vuletić, I.: Granice nehajne odgovornosti za kazneno djelo nesavjesnog liječenja, Zbornik radova Pravnog fakulteta u Splitu, vol. 54, no. 3, 2017, pp. 685 - 704.

21. Mrčela, M.; Vuletić, I., Liječnik i kazneno pravo, Zagreb, 2019

22. Munivrana Vajda, M.; Ivičević Karas, E., Criminal law, Supplement 57, Croatia, International Encyclopedia of Laws, 2016

23. Novoselec, P., Sudska praksa, Hrvatski ljetopis za kazneno pravo i praksu, vol. 19, no. 2, 2012, pp. 937 - 939.

24. Novoselec, P., Bojanić, I., Opći dio kaznenog prava, Zagreb, 2013

25. Novoselec, P., Opći dio kaznenog prava, Osijek, 2016

26. Nys, H., On Medical Liability in Council of Europe Member States, A comparative study of the legal and factual situation in Member states of the Council of Europe, Strasbourg, 2005

27. Ormerod, D, Smith and Hogan Criminal Law, 2011

28. Papagiannopoulos, K., The ideal and impartial medical expert: tips and tricks for a safe medicolegal practice, J Thorac Dis., vol. 11, no. 7, 2019, pp. 1009 - 1013.

29. Petrović, O., Treba li odlučivati između komplikacije i stručne pogreške?, Liječnički vjesnik, vol. 135, 2013, pp. $100-103$.

30. Radišić, J., Odgovornost zbog pogrešne lekarske dijagnoze i nepreduzimanja potrebnih dijagnostičkih mera, Revija za pravo osiguranja, vol. 10, no. 1, 2011, pp. $55-65$.

31. Roksandić Vidlička, S., Aktualna pitanja pojedinih kaznenih djela protiv zdravlja ljudi u svjetlu donošenja nacrta izmjena hrvatskog kaznenog zakona, Godišnjak Akademije pravnih znanosti 1/2010 in Turković, K. et al. (eds.), Hrestomatija hrvatskog medicinskog prava, Pravni fakultet Sveučilišta u Zagrebu, 2016, pp. 811 - 859.

32. Roksandić Vidlička, S, Kaznena djela protiv zdravlja ljudi in Cvitanović, L. et al., Kazneno pravo-Posebni dio, Zagreb, 2018

33. Roksandić Vidlička, S.; Ćepulić, E.; Babić, T., Scandinavian model of insurance from medical error - can it live in framework of Croatian legislative, Zbornik radova, 1. Kongres pravnika u zdravstvu, 2008

34. Roksandić Vidlička, S.; Pražetina Kaleb, R., Utvrdivanje pravnog kontinuiteta i tumačenje elemenata bića kaznenog djela nesavjesnog liječenja, Zbornik radova s međunarodnog kongresa „1. Kongres KOKOZA i 3. Hrvatski kongres medicinskog prava s međunarodnim sudjelovanjem”, Rabac, 2019 
35. Simonović, B., Teret dokazivanja dijagnostičkih grešaka i njihovih posledica, Glasnik prava, no. 6, 1997, pp. $23-39$.

36. Sonederland, K., Medical Malpractice-the Legal Situation in Norway, European Journal of Health Law, no. 3, 1996, pp. 110 - 120.

37. Turković, K.; Roksandić Vidlička, S., Reforma kaznenog zakonodavstva u području zdravstvaKaznena djela protiv zdravlja ljudi de lege ferenda, Zbornik radova Aktualnosti zdravstvenog zakonodavstva i pravne prakse, Novalja, 2011, in Turković, K. et al. (eds.), Hrestomatija hrvatskog medicinskog prava, Pravni fakultet Sveučilišta u Zagrebu, 2016, pp. 860 - 880.

38. Turković, K.; Roksandić Vidlička, S.; Maršavelski, A., Recommendation on alternative dispute resolution in medical liability in Council of Europe member states, Book of proceedings of the 18th World Congress on medical law, 2010. in Turković, K. et al. (eda.), Hrestomatija hrvatskog medicinskog prava, Pravni fakultet Sveučilišta u Zagrebu, 2016, pp. 883 - 894.

39. Vuletić, I., Medical Malpractice as a Separate Criminal Offense: a Higher Degree of Patient Protection or Merely a Sword Above the Doctor's Heads? The Example of the Croatian Legislative Model and the Experiences of its Implementation, Medicine, Law and Society, vol. 12, no. 2, 2019, pp. $39-60$.

40. Vojković, H., Gradanskopravni standard medicinskog tretmana, Zbornik radova Pravnog fakulteta u Splitu, vol. 56, no. 3, 2019, pp. 567 - 591.

41. Watson, K.; Kottenhagen, R., Patients' Rights, Medical Error and Harmonisation of Compensation Mechanisms in Europe, European Journal of Health Law, vol. 25, no. 1, 2017, pp. $1-23$.

42. Zečević, D.; Škavić, J., Kaznenopravna i gradanskopravna odgovornost liječnika - teorija i praksa, Medicinska naklada, Zagreb, 2012

\section{COURT OF JUSTICE OF THE EUROPEAN UNION}

1. Case T-177/13 TestBioTech and Others v. Commision [2016] ECR $I-736$

2. Case C-158/96 Raymond Kohll $v$ Union des caisses de maladie [1998] ECR I-01931

3. Case C-120/95 Nicolas Decker v Caisse de Maladie des Employés Privés [1998] ECR I-01831

4. Case C-173/09 Georgi Ivanov Elchinov v Natsionalna zdravnoosiguritelna kasa, [2010] ECR $I-581$

5. Case C-157/99 B.S.M. Geraets-Smits v Stichting Ziekenfonds VGZ and H.T.M. Peerbooms v Stichting CZ Groep Zorgverzekeringen [2001] ECR I-404

\section{EU LAW}

1. Treaty of Lisbon amending the Treaty on European Union and the Treaty establishing the European Community [2007], OJ C306/1

2. Directive 2005/36/EC of the European Parliament and of the Council of 7 September 2005 on the recognition of professional qualifications [2005], OJ L 255/22

3. Directive 2011/24/EU of the European Parliament and of the Council of 9 March 2011 on the application of patients' rights in cross-border health care [2011], OJ L 88/45 


\section{LIST OF NATIONAL REGULATIONS, ENACTMENTS AND COURT DECISIONS}

1. Decision of the Municipal State Attorney in Split, DO-K-1601/01

2. Judgment of the Municipal Court in Bjelovar, K-105/2009 of 14 September 2011

3. Judgment of the County Court in Bjelovar, KŽ-443 / 2011-3 of 16 February 2012

4. Supreme Court of Croatia, I Kž-124 / 1994-3 of 28 December 1994

5. Supreme Court of Croatia, IV Kž-120/1991-2 of 18 December 1991

6. Supreme Court of Croatia, IV Kž 52/2004-2 of 30 June 2004

\section{WEBSITE REFERENCES}

1. Declaration on the Promotion of Patient's Rights in Europe, [ https://ec.europa.eu/health/ ph_overview/co_operation/mobility/docs/health_services_co108_en.pdf], accessed 30 . January 2020

2. Health Act [http://thomas.loc.gov/cgi-bin/query/F?c109:1:./temp/ c10983ljHe:e1001], accessed 12. December 2019

3. Patients' Rights in the European Union Mapping eXercise, Final Report, available at: [https://ec.europa.eu/health/sites/health/files/cross_border_care/docs/2018_mapping_patientsrights_frep_en.pdf], accessed 30. January 2020 